\title{
Cold resistance in plants: A mystery unresolved
}

\author{
Nishawar Jan \\ Department of Biotechnology \\ The University of Kashmir \\ 190006 ( $\mathrm{J}$ and $\mathrm{K})$, India \\ Mahboob-ul-Hussain \\ Department of Biotechnology \\ The University of Kashmir \\ 190006 ( $\mathrm{J}$ and $\mathrm{K})$, India \\ Khurshid I. Andrabi* \\ Department of Biotechnology \\ New Science Block, Ground Floor \\ The University of Kashmir \\ 190006, Srinagar (J and K), India \\ fax: 911942428723 \\ Email: andrabik@kashmiruniversity.ac.in
}

Financial Support: Fellowship grant from University Grants Commission, India, for Nishawar Jan.

Keywords: cold acclimation, cold resistance, CORs (cold regulated).

Abbreviations: COR: cold-regulated

COS: cold standard set

CSP: cold shock proteins

DREB: dehydratation responsive element-binding factors

LEA: late embryogenesis abundant

MYB: myeloblastosis

MYBRS: MYB recognition elements

RING: really Interesting new gene

SUMO: small ubiquitin-related modifier

Herbaceous temperate plants are capable of developing freezing tolerance when they are exposed to low nonfreezing temperatures. Acquired freezing tolerance involves extensive reprogramming of gene expression and metabolism. Recent full-genome transcript profiling studies, in combination with mutational and transgenic plant analyses, have provided a snapshot of the complex transcriptional network that operates under cold stress. The changes in expression of hundreds of genes in response to cold temperatures are followed by increases in the levels of hundreds of metabolites, some of which are known to have protective effects against the damaging effects of cold stress. Genetic analysis has revealed important roles for cellular metabolic signals, and for RNA splicing, export and secondary structure unwinding, in regulating cold-responsive gene expression and chilling and freezing tolerance. These results along with many of the others summarized here further our understanding of the basic mechanisms that plants have evolved to survive freezing temperatures. In addition, the findings have potential practical applications, as freezing temperatures are a major factor limiting the geographical locations suitable for growing crop and horticultural plants and periodically account for significant losses in plant productivity. Although, great progress has been made in the field but lacunae still remain since it appears that the cold resistance is more complex than perceived and involves more than one pathway.

Cold stress is a major environmental factor that limits the agricultural productivity of plants. Low temperature has a huge impact on the survival and geographical distribution of plants. Cold stress often affects plant growth and crop productivity, which causes significant crop losses (Xin and Browse, 2000). Plants differ in their tolerance to chilling $\left(0-15^{\circ} \mathrm{C}\right)$ and freezing $\left(<0^{\circ} \mathrm{C}\right)$ temperatures. Plants from temperate regions are chilling tolerant, although most are not very tolerant to freezing but can increase their freezing tolerance by being exposed to chilling, non freezing temperatures, a process known as cold acclimation (Levitt, 1980), which is associated with biochemical and physiological changes (Shinozaki and YamaguchiShinozaki, 1996; Thomashow, 1998; Gilmour et al. 2000). By contrast, plants of tropical and subtropical origins, including many crops such as rice, maize and tomato are

*Corresponding author 
sensitive to chilling stress and largely lack the capacity for cold acclimation.

What genes have important roles in cold acclimation? What are their functions? How do plants sense low temperature and activate the cold-acclimation response? These are some of the key questions that investigators working in the field of cold acclimation are actively engaged in answering. Knowledge in these areas is not only important for an overall understanding of how plants sense and respond to changes in the environment, but also has potential practical applications. Determining the nature of the genes and mechanisms responsible for freezing tolerance and the sensing and regulatory mechanisms that activate the coldacclimation response provide the potential for new strategies to improve the freezing tolerance of agronomic plants. Such strategies would be highly significant as traditional plant breeding approaches have had limited success in improving freezing tolerance (Sarhan and Danyluk, 1998). The freezing tolerance of wheat varieties and oilseed varieties developed so far, for instance, are only marginally better than those developed approximately hundred years ago (Fowler and Gusta, 1979; Rapacz and Markowski, 1999).

Classical genetic studies have demonstrated that the ability of plants to cold acclimate is a quantitative trait involving the action of many genes with small additive effects (Thomashow, 1990). In recent years, many approaches have been taken to determine the nature of genes with roles in freezing tolerance: the isolation and characterization of genes induced during cold acclimation; the isolation and characterization of mutants affected in freezing tolerance; and transcriptome analysis. Most molecular studies on plant responses to cold stress are focused on the mechanism of cold acclimation rather than on chilling tolerance. Nevertheless, recent evidence indicates that some of the molecular changes that occur during cold acclimation are also important for chilling tolerance (Gong et al. 2002; Dong et al. 2006). In other words, it appears that chilling tolerance that is exhibited by temperate plants is not entirely constitutive, and that at least part of it is developed during exposure to chilling temperatures.

Numerous physiological and molecular changes occur during cold acclimation (Thomashow, 1999). Among them, the transcriptional activation and repression of genes by low temperature are of central importance (Thomashow, 1999). The reprogramming of gene expression results in the accumulation not only of protective proteins but also of hundreds or more of metabolites, some of which are known to have protective effects.

\section{Freezing injury and tolerance mechanisms}

Cold temperature affects a broad spectrum of cellular components and metabolism, and temperature extremes impose stresses of variable severity that depend on the intensity and duration of the stress. Wide ranges of studies indicate that the membrane systems of the cell are the primary site of freezing injury in plants (Levitt, 1980; Steponkus, 1984). In addition, it is well established that freeze-induced membrane damage results primarily from the severe dehydration associated with freezing (Steponkus, 1984; Steponkus et al. 1993). As temperatures drops below $0^{\circ} \mathrm{C}$, ice formation is generally initiated in the intercellular spaces due, in part, to the extracellular fluid having a higher freezing point (lower solute concentration) than the intracellular fluid. Because the chemical potential of ice is less than that of liquid water at a given temperature, the formation of extracellular ice results in a drop in water potential outside the cell. Consequently, there is movement of unfrozen water down the chemical potential gradient from inside the cell to the intercellular spaces (Figure 1). At $10^{\circ} \mathrm{C}$, more than $90 \%$ of the osmotically active water typically moves out of the cells, and the osmotic potential of the remaining unfrozen intracellular and intercellular fluid is greater than 5 osmolar.

Multiple forms of membrane damage can occur as a consequence of freeze induced cellular dehydration including expansion-induced-lysis, lamellar-to-hexagonalII phase transitions (Figure 2), and fracture jump lesions (Steponkus et al. 1993).Thus, a key function of cold acclimation should be to stabilize membranes against freezing injury. Indeed, cold acclimation prevents expansion-induced-lyses and the formation of hexagonal II phase lipids in rye and other plants (Steponkus et al. 1993). Multiple mechanisms appear to be involved in this stabilization. The best documented are changes in lipid composition (Steponkus et al. 1993). Membrane fluidity is largely dictated by the composition of lipid molecular species, the degree of lipid saturation and temperature environments. Temperature induced change in membrane fluidity is one of the immediate consequences in plants during temperature stresses and might represent a potential site of perception and/or injury (Horváth et al. 1998; Orvar et al. 2000). The importance of proper membrane fluidity in temperature tolerance has been delineated by mutation analysis, transgenic and physiological studies. At low temperature, greater membrane lipid unsaturation appears to be crucial for optimum membrane function. An Arabidopsis fatty acid biosynthesis FAB1 mutant with more saturated membranes showed decreased quantum efficiency of photosystem II (PSII), chlorophyll content and the amount of chloroplast glycerolipids after prolonged exposure to low temperature ( $\mathrm{Wu}$ et al. 1997). A triple mutant fatty acid desaturation (fad3-2 fad7-2 fad8) devoid of trienoic fatty acids (18:3 or 16:3) produced a phenotype similar to FAB1 when plants were subjected to prolonged low temperature exposure (Routaboul et al. 2000). Similarly, fad5 and fad6 mutants with more saturated membranes became chlorotic and showed growth retardation during low temperature incubation (Hugly and Somerville, 1992). In addition to membrane unsaturation, it appears that lipid asymmetry in the membrane also contributes to membrane physical structure at low temperature (Gomès et al. 2000). When overexpressed in 


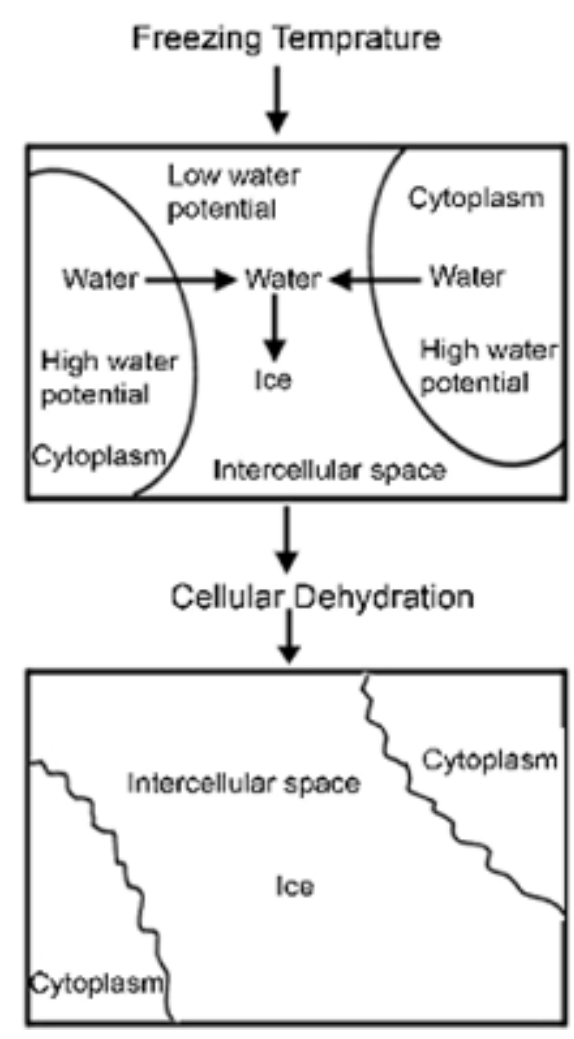

Figure 1. Diagrammatic representation of the mechanism of cellular dehydration at freezing temperatures.

yeast, aminophospholipid ATPase1 (ALA1), a putative aminophospholipid translocase in Arabidopsis, restored phosphatidylserine internalization from the outer leaflet of the plasma membrane. The finding supports the fact that internalization of phosphatidylserine was tightly linked to the rescue of a cold sensitivity phenotype of the yeast drs2 mutant (Gomès et al. 2000).

The accumulation of sucrose and other simple sugars that typically occurs with cold acclimation also seems likely to contribute to the stabilization of membranes as these molecules can protect membranes against freeze-induced damage in vitro (Strauss and Hauser, 1986; Anchordoguy et al. 1987). In addition, there is emerging evidence that certain novel hydrophilic and late embryogenesis abundant (LEA) polypeptides also participate in the stabilization of membranes against freeze-induced injury. These hydrophilic and late embryogenesis abundant polypeptides are predicted to contain regions capable of forming amphipathic $\alpha$-helices which are shown to have strong effect on intrinsic curvature of monolayers and their propensity to form hexagonal II phase. They are said to defer their formation at lower temperatures (Epand et al. 1995). Whether the regions predicted to form amphipathic $\alpha$-helices actually form such structures is uncertain. An additional hypothesis suggests that the extensive water binding capacity of these hydrophilic proteins might provide a protective environment in the proximity of membranes during freezing and result in membrane stabilization. Although freezing injury is thought to result primarily from membrane lesions caused by cellular dehydration, additional factors may also contribute to freezing-induced cellular damage. There is evidence that freeze-induced production of reactive oxygen species contributes to membrane damage and that intercellular ice can form adhesions with cell walls and membranes and cause cell rupture (Olien and Smith, 1977). In addition, there is evidence that protein denaturation occurs in plants at low temperature (Guy et al. 1998) which could potentially result in cellular damage. In these cases, the enhancement of antioxidative mechanisms (Aroca et al. 2003), increased levels of sugars in the apoplastic space (Livingston and Henson, 1998), and the induction of genes encoding molecular chaperones (Guy and $\mathrm{Li}, 1998$ ), respectively, could have protective effects.

Both cold-stress-induced transcripts and constitutively expressed transcripts need to be processed, exported to the cytoplasm and kept in conformations that are competent for translation. RNA can fold into extensive secondary structures that could interfere with its function, and cold temperatures exacerbate this interference. In bacteria, nucleic-acid-binding cold shock proteins (CSPs) accumulate at cold temperatures and function as transcription antiterminators or translational enhancers by destabilizing RNA secondary structure (Jones and Inouye, 1994). Some CSP-domain-containing proteins in plants are upregulated by cold stress, and might function as RNA chaperones in the regulation of translation (Nakaminami et al. 2006; Kim et al. 2007). A different cold-responsive nucleic-acid-binding protein, a zincfinger- containing glycine-rich RNA-binding protein from Arabidopsis designated atRZ-1a, is also upregulated by cold stress, and genetic analysis supports its function in freezing tolerance (Kim et al. 2005). Another group of RNA chaperones, RNA helicases, are involved in every step of RNA metabolism. In cyanobacteria, a cold-induced DEAD-box RNA helicase was suggested to unwind cold-stabilized secondary structure in the 5'-untranslated region of RNA during cold stress (Yu and Owttrim, 2000). Compared to other organisms, plants have the largest number of DEAD-box RNA helicase genes. One of these helicases, which is encoded by the Arabidopsis low expression of osmotically responsive genes4 (LOS4) gene, is essential for plant tolerance of chilling and freezing stress (Gong et al. 2002). LOS4 is required for efficient export of RNA from the nucleus to the cytoplasm (Gong et al. 2005). The Arabidopsis nucleoporin AtNUP160 suppressor of auxin resistance1 (SAR1) also controls RNA export, and is crucial for chilling and freezing tolerance (Dong et al. 2006). Both LOS4 and AtNUP160 proteins are enriched at the nuclear rim (Gong et al. 2002; Dong et al. 2006). Defects in the nucleocytoplasmic transport of RNA seem to affect cold tolerance preferentially, because the LOS4 and AtNUP160 mutant plants do not have severe growth or 
developmental phenotypes, nor are they strongly altered in the tolerance of other abiotic stresses.

\section{Cold responsive pathways and the players involved}

The discovery of Gene expression change during cold acclimation was the starting of exploration of antifreezing molecular mechanisms. Global transcript profiling analyses indicate that $>10 \%$ of genes in the Arabidopsis genome are regulated during cold acclimation (Fowler and Thomashow, 2002; Kreps et al. 2002; Seki et al. 2002; Vogel et al. 2005). Transcriptome analysis using microarray technology is a powerful technique, which has proven very useful for discovering many stress-inducible genes involved in stress response and tolerance (Shinozaki et al. 2003; Seki et al. 2004). Numerous genes that are induced by various abiotic stresses have been identified using various microarray systems (Kawasaki et al. 2001; Seki et al. 2001; Fowler and Thomashow, 2002; Kreps et al. 2002; Seki et al. 2002; Rabbani et al. 2003; Bray, 2004; Maruyama et al. 2004; Vogel et al. 2005). Genes induced during stress conditions function not only in protecting cells from stress by producing important metabolic proteins, but also in regulating genes for signal transduction in the stress response. Thus, these gene products are classified into two groups (Fowler and Thomashow, 2002; Kreps et al. 2002; Seki et al. 2002). The first group includes proteins that probably function in stress tolerance, such as chaperones, LEA proteins, osmotin, antifreeze proteins, mRNA-binding proteins, key enzymes for osmolyte biosynthesis such as proline, water channel proteins, sugar and proline transporters, detoxification enzymes, enzymes for fatty acid metabolism, proteinase inhibitors, ferritin, and lipid-transfer proteins. Some of these stress-inducible genes that encode proteins, such as key enzymes for osmolyte biosynthesis, LEA proteins, and detoxification enzymes have been overexpressed in transgenic plants and produce stresstolerant phenotypes in the transgenic plants (Holmberg and Bulow, 1998; Cushman and Bohnert, 2000). These results indicate that the gene products of the stress-inducible genes really function in stress tolerance. The second group contains protein factors involved in further regulation of signal transduction and gene expression that probably function in stress response. They include various transcription factors that regulate various stress-inducible genes cooperatively or separately, and may constitute gene networks. Some of these regulatory pathways are also involved in other stress responses including those of drought-, cold-, or high-salinity (Seki et al. 2003). Functional analysis of these stress-inducible transcription factors should provide more information on the complex regulatory gene networks that are involved in responses to drought, cold, and high-salinity stresses. The others are proteins kinases, protein phosphatases, enzymes involved in phospholipids metabolism, and other signaling molecules such as calmodulin-binding protein and 14-3-3 proteins. At present, the functions of most of these genes are not fully understood. Some of these stress-inducible regulatory genes that encode proteins such as transcription factors have been overexpressed in transgenic plants and generate stresstolerant phenotypes in them (Zhang et al. 2004; Tester and Bacic, 2005; Vinocur and Altman, 2005).

The large number of genes identified in these studies raises the question of exactly which genes are most central to increasing freezing tolerance. One approach towards answering this question has been to focus on a set of genes that encode a related family of cold-regulated (COR) proteins, which are massively induced during cold acclimation (Hajela et al. 1990; Gilmour et al. 2004). Some of these COR genes have also been named low temperature-induced (LTI), cold acclimation-specific (CAS), cold-induced (KIN), and responsive to drought (RD) genes (Kurkela and Franck, 1990; YamaguchiShinozaki et al. 1992; Monroy et al. 1993; Nordin et al. 1993). The COR genes were used by two research groups to identify a family of Arabidopsis transcription factors known as either C-repeat binding factors (CBF) (CBF1, $\mathrm{CBF} 2$ and $\mathrm{CBF} 3$ ) or dehydration responsive elementbinding factors (DREB) (DREB1B, DREB1C and DREB1A) (Stockinger et al. 1997; Gilmour et al. 1998; Liu et al. 1998). CBFs/DREBs are upstream transcription factors that bind to promotor cis element CRT/ DRE and activate the expression of these cold responsive genes (Thomashow, 1999). Ectopic transgenic overexpression of CBF1/ DREB1B, CBF2/DREB1C or CBF3/DREB1A in Arabidopsis activates a suite of CBF/DREB target genes at warm temperatures (Gilmour et al. 2004) and results in increased freezing, drought and salt tolerance (JagloOttosen et al. 1998; Liu et al. 1998; Kasuga et al. 1999; Gilmour et al. 2004). CBF transcripts begin accumulating within 15 min of plants being exposed to low temperature strongly suggests that the low temperature "Thermometer" and "Signal Transducer" are present at warm non-inducing temperatures (Gilmour et al. 1998). Gilmour et al. 1998 have, therefore, proposed that there is a transcription factor already present at warm temperature that recognizes the CBF promoters. This factor would not appear to be the $\mathrm{CBF}$ proteins themselves as the promoters of the $\mathrm{CBF}$ genes lack the CRT/DRE sequence and overexpression of CBF1 does not cause accumulation of CBF3 transcripts (Gilmour et al. 1998). Gilmour et al. 1998 have, therefore, proposed that COR gene induction involves a two-step cascade of transcriptional activators in which the first step, CBF induction, involves an unknown activator that they tentatively designated "ICE" (inducer of CBF expression (ICE)) (Figure 3). ICE presumably recognizes a coldregulatory element, the "ICE Box," present in the promoters of each CBF gene. At warm temperature, ICE is suggested to be in an "inactive" state, either because it is sequestered in the cytoplasm by a negative regulatory protein or is in a form that does not bind to DNA or does not activate transcription effectively. Upon exposing a plant to low temperature, however, a signal transduction pathway is suggested to be activated those results in modification of either ICE or an associated protein, which, in turn, allows ICE to induce CBF gene expression. Indeed, in Arabidopsis 

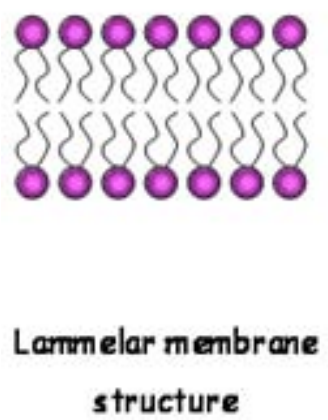
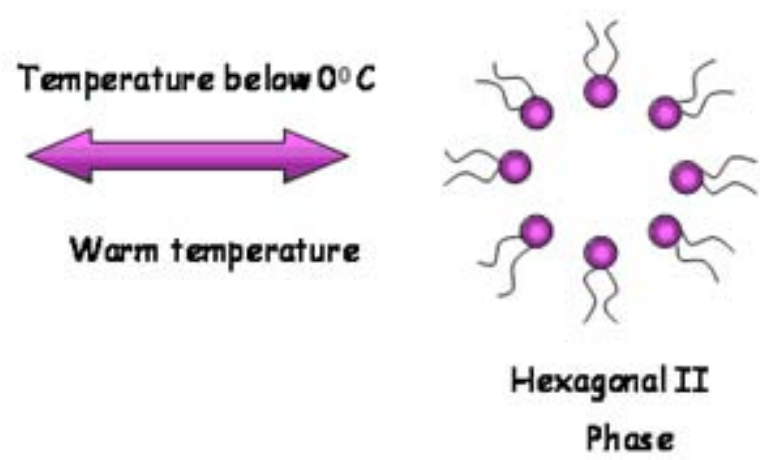

\section{Figure 2. Diagrammatic representation of the transition of membrane structure from Lamellar to Hexagonal II phase at freezing} temperatures and vice versa at warm temperatures.

ICE is phosphorylated in response to cold treatment (Teige et al. 2004). As noted by Gilmour et al.1998, it is possible that ICE may not only regulate the expression of the CBF genes, but might induce expression of other genes ("X") that may also have roles in cold acclimation. A dominant mutation in ICE1 leads to the irregular induction of CBF3 transcription factor, an alteration of CBF-regulated genes, and a loss of freezing tolerance (Chinnusamy et al. 2003; Lee et al. 2005). HOS1, a negative regulator of the CBF regulon, was identified from a genetic screen for mutants with deregulated expression of CBF target genes (Ishitani et al. 1998, Lee et al. 2001). It is ubiquitously expressed in all plant tissues and HOS1 protein residues in the cytoplasm at normal growth temperatures. However, in response to low temperature treatments, it accumulates in the nucleus (Lee et al. 2001). The cold induction of CBF genes and their downstream COR genes is enhanced in loss-of-function HOS1 mutant plants (Ishitani et al. 1998). HOS1 encodes a 915-amino acid protein that contains a short motif near the amino terminus that is similar to the really interesting new gene (RING)-finger domain found in the inhibitor of apoptosis (IAP) group of animal proteins (Lee et al. 2001). In vitro ubiquitination assays demonstrated that Arabidopsis HOS1 is a functional RING-finger protein that has ubiquitin E3 ligase activity. HOS1 physically interacts with ICE1, suggesting that HOS1 might ubiquitinate ICE1 and target it for proteosomal degradation. Indeed, both in vitro and in vivo ubiquitination assays showed that HOS1 mediates the polyubiquitination of ICE1 (Dong et al. 2006). Cold-induced degradation of the ICE1 protein was observed in Arabidopsis plants and this degradation is blocked by the HOS1 mutation, indicating that HOS1 is required for the degradation of ICE1, which functions to attenuate cold responses in Arabidopsis (Dong et al. 2006). ICE1 and perhaps related transcription factors that control the expression of CBF genes are present in the absence of cold stress, but probably undergo certain posttranslational modification(s) (e.g. phosphorylation) in response to cold stress, thereby becoming active in switching on the expression of CBF genes (Chinnusamy et al. 2003). The active, modified form of ICE1 might be more efficiently recognized by HOS1 and then degraded through the ubiquitination/proteasome pathway.

Sumoylation/desumoylation of proteins has been shown to have a pivotal role in cold acclimation (Miura et al. 2007). Sumoylation is a post-translational protein modification where small ubiquitin-related modifier (SUMO) proteins are conjugated to protein substrates in a process dependent on SUMO E3 ligases, whereas desumoylation is the removal of SUMO proteins from their target proteins by SUMO proteases. It might protect target proteins from proteasomal degradation because sumoylation prevents ubiquitination (Ulrich, 2005). SIZ1, an Arabidopsis SUMO E3 ligase is shown to be required for the accumulation of SUMO conjugates during cold stress, and the SIZ1 null mutant is hypersensitive to chilling and freezing stresses. The cold-induction of CBFs and its target COR genes [COR15A, COR47 and KIN1] is significantly reduced in SIZ1 null mutants, but it enhances the cold induction of AtMYB15, a negative regulator of CBFs. In contrast to HOS1, which promotes the proteolysis of ICE1, SIZ1 mediates SUMO conjugation to K393 of ICE1 during cold acclimation, and this reduces polyubiquitination of ICE1. A K393R substitution in ICE1 [ICE1(K393R)], blocks the SIZ1-mediated sumoylation and ICE1(K393R) overexpressing transgenic plants exhibit a moderate increase in myeloblastosis (MYB)15 expression under cold stress, and display a hypersensitivity to freezing stress similar to ICE1 mutant plants. Transgenic Arabidopsis plants overexpressing ICE1 but not ICE1(K393R) exhibit an enhanced cold induction of CBFs and increased freezing tolerance. These results suggest that SIZ1-mediated sumoylation might facilitate ICE1 stability and activity, which is necessary for CBF expression and MYB15 repression to fine-tune the transcription of COR genes during cold acclimation (Figure 3) (Miura et al. 2007). 
Table 1. Transcription factors and structural genes as transgenes for anti-freeze engineering.

\begin{tabular}{|c|c|c|c|c|}
\hline Gene/Source & Function & Target & Phenotype and effects & Reference \\
\hline $\begin{array}{l}\text { CBF1,CBF3,CBF4/ } \\
\text { Arabidopsis }\end{array}$ & TF & Arabidopsis & $\begin{array}{l}\text { Freezing, salt and drought tolerance; } \\
\text { constitutive expression of COR genes }\end{array}$ & $\begin{array}{l}\text { Jaglo-Ottosen et al. 1998; Liu et al. 1998; Gilmour } \\
\text { et al. 2000; Haake et al. } 2002\end{array}$ \\
\hline $\begin{array}{l}\text { CBF1,CBF2,CBF3/ } \\
\text { Arabidopsis }\end{array}$ & TF & B. napus & $\begin{array}{l}\text { Freezing and drought tolerance; constitutive } \\
\text { expression of BN115 and BN28 }\end{array}$ & Jaglo et al. 2001 \\
\hline $\begin{array}{l}\text { CBF1/ } \\
\text { Arabidopsis }\end{array}$ & TF & Strawberry & Freezing tolerance & Owens et al. 2002 \\
\hline $\begin{array}{l}\text { OsDREB1A/ } \\
\text { Rice }\end{array}$ & TF & Arabidopsis & Drought, salt and freezing tolerance & Dubouzet et al. 2003 \\
\hline $\begin{array}{l}\text { SCOF1/ } \\
\text { Soybean }\end{array}$ & TF & Arabidopsis & Tolerant to chilling and freezing & Kim et al. 2001 \\
\hline $\begin{array}{l}\text { ICE1/ } \\
\text { Arabidopsis }\end{array}$ & TF & Arabidopsis & Freezing tolerance & Chinnusamy et al. 2003 \\
\hline $\begin{array}{l}\text { FRS1/ } \\
\text { Arabidopsis }\end{array}$ & TF & Arabidopsis & Freezing sensitive & Llorente et al. 2000 \\
\hline $\begin{array}{l}\text { HOS2l } \\
\text { Arabidopsis }\end{array}$ & TF & Arabidopsis & Freezing sensitive & Lee et al. 1999 \\
\hline $\begin{array}{l}\text { ESK1/ } \\
\text { Arabidopsis }\end{array}$ & TF & Arabidopsis & Constitutive freezing tolerance & Xin and Browse, 1998 \\
\hline $\begin{array}{l}\text { CAP } 160 \text { and } \\
\text { CAP } 85 / \text { Spinach }\end{array}$ & $\begin{array}{l}\text { Dehydrin and } \\
\text { Lea-like }\end{array}$ & Tobacco & Marginal increase of tolerance & Kaye et al. 1998 \\
\hline CuCOR19/Citrus & Lea-like & Tobacco & Freezing tolerance & Hara et al. 2003 \\
\hline WCOR410/Wheat & Dehydrin & Strawberry & Freezing tolerance & Houde et al. 2004 \\
\hline WCS19/Wheat & Dehydrin & Arabidopsis & Freezing tolerance & Ndong et al. 2002 \\
\hline Mn-SOD/ Alfalfa & $\begin{array}{l}\text { AOS } \\
\text { metabolism }\end{array}$ & Alfalfa & $\begin{array}{l}\text { Modest increase on freezing } \\
\text { tolerance }\end{array}$ & McKersie et al. 1999 \\
\hline $\begin{array}{l}\text { Fe-SOD / } \\
\text { Alfalfa }\end{array}$ & $\begin{array}{l}\text { AOS } \\
\text { metabolism }\end{array}$ & Alfalfa & $\begin{array}{l}\text { Increased winter survival, } \\
\text { but no difference in shoot } \\
\text { dry-matter yield }\end{array}$ & McKersie et al. 2000 \\
\hline SbwAFP/Spruce & AFP & Tobacco & Freezing tolerant & Holmberg et al. 2001 \\
\hline $\begin{array}{l}\text { Proline } \\
\text { dehydrogenase/ } \\
\text { Arabidopsis }\end{array}$ & $\begin{array}{l}\text { Amino acid } \\
\text { metabolism }\end{array}$ & Arabidopsis & Enhanced freezing tolerance & Nanjo et al. 1999 \\
\hline
\end{tabular}


Feedback repression of transcription factors that regulate cold-responsive gene expression appears to be a key to maintaining an optimal cold-induced transcriptome. Molecular analysis of a CBF2 null mutant of Arabidopsis suggested that CBF2 is a negative regulator of CBF1 and CBF3 expression during cold acclimation (Novillo et al. 2004). Conversely, CBF3 might negatively regulate CBF2 expression, because reduced expression of CBF3 in the ice1 mutant is accompanied by an enhanced expression of CBF2 (Chinnusamy et al. 2003). These results suggest that crossregulation and, perhaps, also self-regulation have an important role in the expression levels of CBFs during cold acclimation (Figure 3). Furthermore, CBFs are negatively regulated by an upstream transcription factor, MYB15 (an R2R3-MYB family protein) in Arabidopsis. MYB15 is expressed even in the absence of cold stress, and MYB15 can bind to MYB recognition elements (MYBRS) in the promoters of CBFs. MYB15 TDNA knockout mutant plants show enhanced expression of CBFs during cold acclimation and enhanced freezing tolerance, whereas transgenic Arabidopsis overexpressing MYB15 show a decreased expression of CBFs and a reduction in freezing tolerance. Thus, MYB15 is an upstream transcription factor that negatively regulates the expression of CBFs (Agarwal et al. 2006) (Figure 3). Interestingly, ICE1 can negatively regulate MYB15 as indicated from the increased MYB15 transcript level in ICE1 mutant compared with wild-type plants under cold stress (Chinnusamy et al. 2003; Agarwal et al. 2006). Yeast two-hybrid and in vitro pull-down assays showed that MYB15 can interact with ICE1, but the functional significance of ICE1-MYB15 interaction in cold acclimation is unknown (Agarwal et al. 2006). In Arabidopsis, a cold-induced $\mathrm{C} 2 \mathrm{H} 2$ zinc finger transcription factor gene, ZAT12, also appears to function as a negative regulator of CBFs (Figure 3). Transgenic overexpression of ZAT12 decreases the expression of CBFs under cold stress. Transcriptome analysis of ZAT12-overexpressing Arabidopsis revealed that the ZAT12 regulon consists of at least 24 cold standard set (COS) genes, of which nine are cold-induced and 15 are cold-repressed genes (Vogel et al. 2005). Molecular analysis of the LOS2 mutant of Arabidopsis revealed that another $\mathrm{C} 2 \mathrm{H} 2$ zinc finger protein, ZAT10/STZ, might act as a negative regulator of CBFtarget genes. LOS2, a bifunctional enolase, binds to the MYC recognition elements in the ZAT10 promoter in vitro and LOS2 mutant plants showed an enhanced and more sustained induction of ZAT10 during cold stress (Lee et al. 2002). Thus LOS2 appears to be a negative regulator of ZAT10 expression during cold acclimation. Transient expression assays showed that ZAT10 could bind specifically to $A(G / C) T$ promotor cis element within the EP2 sequence (a cis element where a negative regulator binds) of RD29A, a target gene of CBFs, and repress its expression (Lee et al. 2002). CBFs might have a role in mediating or modulating cold-stress induction of ZAT10 because transgenic plants overexpressing CBF3 showed an enhanced expression of ZAT10 (Maruyama et al. 2004). Furthermore, impairment of CBF3 expression caused by the ICE1 mutation also led to a significant decrease in the cold induction of ZAT10, as is evident from microarray data (Chinnusamy et al. 2003; Chinnusamy et al. 2006). Thus, ZAT10 could be a subregulon of CBFs and might regulate a subset of genes involved in cold acclimation (Figure 3). ZAT10 and ZAT12 might serve as converging nodes in abiotic stress-regulated transcriptional networks, because these transcription factors are induced by cold and other abiotic stresses, and transgenic plants overexpressing these genes exhibit enhanced osmotic and oxidative stress tolerance (Davletova et al. 2005; Mittler et al. 2006).

The homologous components of the Arabidopsis CBF cold response pathway have been found in many plants, including rape (Brassica napus), soybean (Glycine max), broccoli (Brassica oleracea), tomato (Lycopersicon esculentum), alfalfa (Medicago sativa), tobacco (Nicotiana tabacum), cherry (Prunus avium), wheat (Triticum aestivumfrom), rye (Secale cereale), corn (Zea mays), rice (Oryza sativa), strawberry (Fragaria ananassa) and barley (Hordeum vulgare) (Jaglo et al. 2001; Choi et al. 2002; Gao et al. 2002; Owens et al. 2002; Dubouzet et al. 2003; Vágújfalvi et al. 2003; Xue, 2003; Francia et al. 2004). Many of the putative orthologs have been structure analyzed and functionally tested. The expression patterns of the CBFs and CORs in response to low temperature are similar in a variety of plants species, involving rapid coldinduced expression of the CBFs followed by expression of CBF-targeted genes that increase freezing tolerance. Moreover, constitutive overexpression of the Arabidopsis CBF genes in other plants resulted in increased freezing tolerance. Similarly, constitutive overexpression of CBF homologs from other plants in transgenic Arabidopsis also results in salt, cold, and drought tolerance (Table 1). More and more data suggest that components of the Arabidopsis CBF cold-responsive pathway are conserved in higher plants (Figure 3).

Understanding the molecular mechanisms that plants have evolved to tolerate environmental stresses has the potential to provide new tools and strategies to improve the environmental stress tolerance of crops. Since freezing tolerance is a multigenic trait (Thomashow, 2001), transformation of a single functional gene like cor15a appears to have a limited effect on crop freezing tolerance (Artus et al. 1996). Because many aspects of cold adaptation process are under transcriptional control, many transcription regulatory factors were chosen as one of the best targets for engineering crops to achieve enhanced cold tolerance. Overexpression of Arabidopsis CBF/DREB1 genes, which locate the nodes of regulatory network in cold response, or homologs from other plants can activate a group of downstream functional genes, such as KIN1, COR6.6, COR15a, RD17, RD29a and ERD10 in Arabidopsis. For example, constitutive expression of CBF3 genes in Arabidopsis not only elevated levels of COR proteins, but also elevated levels of proline and total sugars, resulting in an increase in both freezing and drought tolerance (Gilmour et al. 2000). Thus, the CBFs appear to be "master switches"' that integrate activation of multiple 


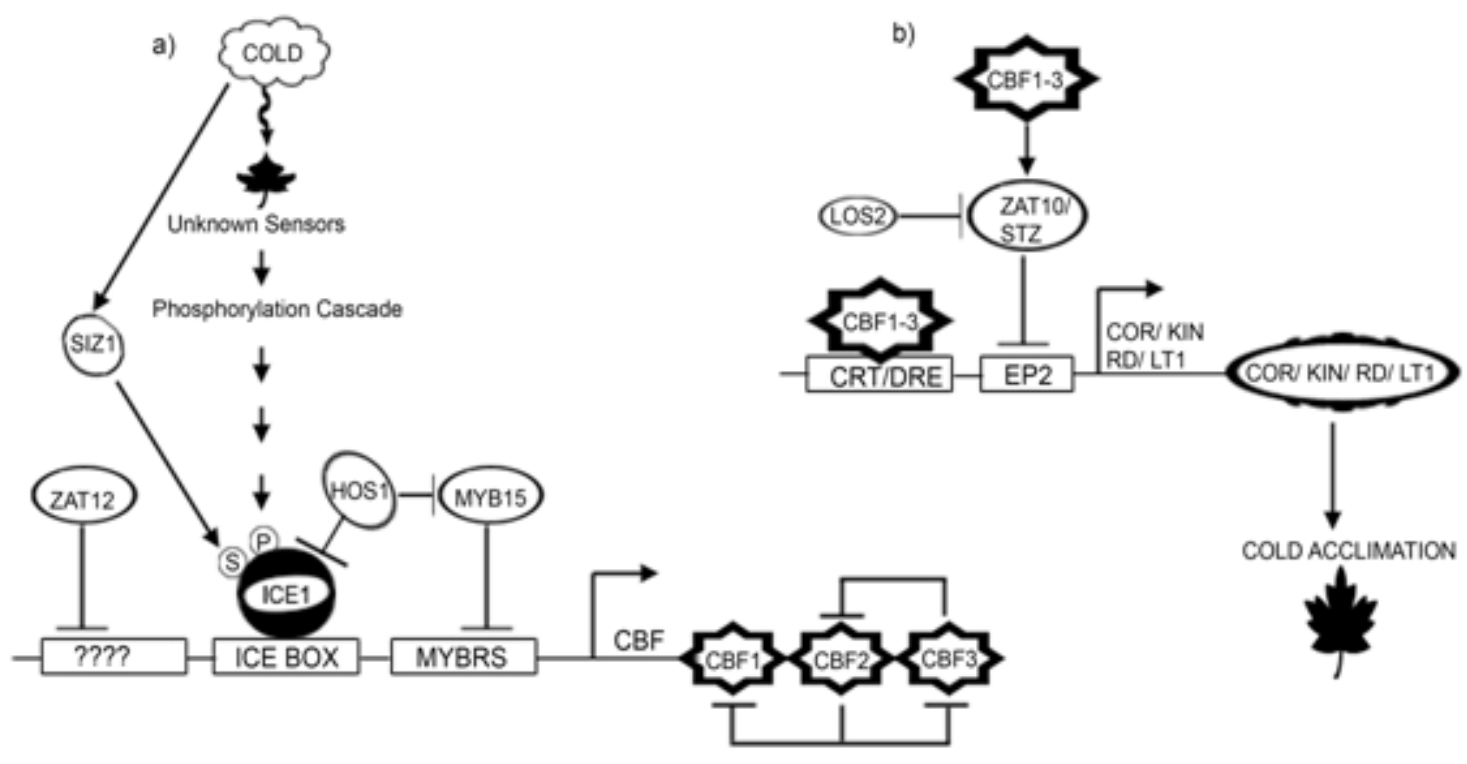

Figure 3. Schematic illustration of cold response network in Arabidopsis.

a) Cold sensing and signaling leads to the activation of multiple transcriptional cascades, one of which involves ICE1 and CBFs. Cold stress induces sumoylation and phosphorylation of constitutively expressed ICE1 that is critical for ICE1-activated transcription of CBFS and repression of MYB15. The expression of CBFs is negatively regulated by MYB15 and ZAT12. HOS1 negatively regulates CBF regulons by targeting ICE1 for proteosomal degradation. CBFs might cross-regulate the each other's transcription. b) CBFs regulate the expression of COR/KIN/RD genes that confer freezing tolerance. CBFs induce the expression of ZAT10/STZ which might downregulate the expression of COR genes. Cold upregulated LOS2 represses the transcription of ZAT10. Arrows indicate activation, whereas lines ending with a bar show negative regulation; "? ? ?" indicate unknown cis-element. Abbreviations: CBF, C-repeat binding factor (an AP2type transcription factor); CRT, C-repeat elements; DRE, dehydration-responsive elements; HOS1, high expression of osmotically responsive genes1 (a RING finger ubiquitin E3 ligase); ICE1, inducer of CBF expression 1; LOS2, low expression of osmotically responsive genes 2; MYB, myeloblastosis; MYBRS, MYB transcription factor.

components of the cold acclimation response (Thomashow, 2001). However, constitutive overexpression of the CBF genes using the cauliflower mosaic virus $35 \mathrm{~S}$ promoter can result in undesirable agronomic traits. In Arabidopsis, CBF overexpression can cause a "stunted" growth phenotype, a decrease in seed yield and a delay in flowering (Liu et al. 1998, Gilmour et al. 2000). Using stress-inducible (Kasuga et al. 1999) or artificial cold-inducible promoters may be an ideal approach to improve cold tolerance without causing negative agronomic effects. Stress inducible promoters that have low background expression under normal growth condition have been used in conjunction with the DREB1/CBF genes to achieve increased stress tolerance without growth retardation (Kasuga et al. 1999). Constitutive overexpression of Arabidopsis DREB1A improved drought and low-temperature stress tolerance in tobacco, and regulation of transgene expression via the stress-inducible RD29A promoter minimized the negative effects on plant growth (Kasuga et al. 2004). Similarly, the Arabidopsis DREB1A gene was placed under control of the RD29A promoter and transferred via biolistic transformation into bread wheat (Pellegrineschi et al. 2004). In comparison with controls, plants expressing the DREB1A gene exhibited a 10-day delay in wilting when water was withheld. This substantial increased resistance to water stress indicates that a combination of the RD29A promoter and DREB1A is useful for improvement of various kinds of transgenic plants that are tolerant to environmental stress. Though many transcription regulatory factors were cloned and identified, only CBF genes have been successfully used to engineer cold stress tolerance in several species. Transgenic attempts with many structural genes have also been made with fair degree of success. The overexpression of genes encoding LEA proteins can improve the stress tolerance of transgenic plants. Expression of the citrus gene encoding a LEA protein, CuCOR19 increased the cold tolerance of transgenic tobacco (Hara et al. 2003). Likewise, the freezing tolerance of Arabidopsis was increased by the ectopic expression of the wheat gene WCS19 (NDong et al. 2002), the Arabidopsis gene COR15A (Artus et al. 1996), and the coexpression of the genes RAB18 and COR47, and XERO2 and ERD10 (Puhakainen et al. 2004). The freezing tolerance of strawberry leaves was enhanced by expression of the wheat dehydrin gene WCOR410 (Houde et al. 2004). On the other hand, the expression of two cold-induced LEA proteins from spinach (Kaye et al. 1998) and three desiccation-induced LEA proteins from C. plantagineum (Iturriaga et al. 1992) in tobacco did not induce any significant changes in the freezing or drought tolerance of the respective transgenic plants. This may indicate either that not all LEA proteins make a significant contribution to plant stress tolerance, or that they need a particular background to function in, as suggested for transgenic 
strawberry plants (Houde et al. 2004). Some of the important genes that have been used in anti-freezing engineering with reasonable success are listed in Table 1.

Previous studies have established that the CBF cold responsive pathway is an integral component of the cold acclimation response (Shinozaki and YamaguchiShinozaki, 2000; Thomashow et al. 2001). However, the transcriptome data showed that additional cold-regulatory pathways also exist (Fowler and Thomashow, 2002; Kreps et al. 2002). Transcriptome comparisons indicated that only $12 \%$ of the cold-responsive genes are certain members of the $\mathrm{CBF}$ regulon. Moreover, at least $28 \%$ of the coldresponsive genes were not regulated by the $\mathrm{CBF}$ transcription factors, including 15 encoding known or putative transcription factors, indicating that these coldresponsive genes are members of different low-temperature regulons. Information about the complexity of cold acclimation also comes from genetic studies using a luciferase gene driven by the COR78/RD29A promoter (Ishitani et al. 1998). A large number of mutants were isolated that are defective in the induction of this fusion gene in response to cold, drought, salinity and ABA treatment. These mutants fall into three major classes based upon the response of osmotically regulated genes: HOS have high expression, LOS display low expression and COS show constitutive activity of these genes (Ishitani et al. 1997). Forward genetic analysis in Arabidopsis identified two transcription factors, high expression of osmotically responsive genes 9 (HOS9) and HOS10, which are required for basal freezing tolerance (Zhu et al. 2004; Zhu et al. 2005). The HOS9 and HOS10 genes encode homeodomain and MYB (AtMYB8) transcription factors, respectively, and their transcript levels are not cold responsive. Loss-of-function mutations in these genes cause significant decreases in basal and acquired freezing tolerance. Interestingly, the mutants show stronger or earlier cold-induction of several CBF-target genes, such as RD29A and COR15A, but no effects on the expression of CBFs. These results suggest a crucial role in freezing tolerance for regulons that are not cold responsive, and these presumably constitutive regulons have a negative effect on the cold responsive CBF regulon.

Microarray analysis led to the identification of the coldstress-inducible AP2 family transcription factor gene related to ABI3/VP1 (RAV1) (Fowler and Thomashow, 2002; Vogel et al. 2005) that might regulate plant growth under cold stress. RAV1 is downregulated by epibrassinolide, and transgenic Arabidopsis overexpressing RAV1 exhibits a retardation of lateral root and rosette-leaf development, whereas antisense RAV1 plants show an early-flowering phenotype (Hu et al. 2004).

The importance of CBF-independent pathways is also supported by analysis of mutants that have increased freezing tolerance. Mutations in eskimo1 (ESK1), a protein of unknown function, result in constitutive freezing tolerance, but the genes that are affected by the ESK1 mutation are distinct from those of the CBF regulon (Xin et al. 2007). Similarly, mutations in the transcriptional adaptor protein ADA2 also cause constitutive freezing tolerance but not constitutive expression of COR genes (Vlachonasios et al. 2003).

Although, a great majority of the highly cold-inducible genes are regulated by CBF transcription factors and other transcription factors ZAT12 and RAV1 identified from transcript profiling studies, the basis for the regulation of the remaining $70 \%$ of the cold-induced COS genes and 95\% cold-repressed COS genes is unknown (Vogel et al. 2005)). Elucidation of the mechanism regulating these coldregulated genes is an important goal in achieving a full understanding of cold acclimation. Taken together, these results demonstrate the complex and interactive relationships among different pathways regulated by cold acclimation.

\section{FUTURE PROSPECTS}

Applications of genomic approaches and gene knockout strategies are beginning to accelerate efforts to assess systematically and understand complex quantitative traits such as acquired tolerance to temperature extremes. By using genetic and molecular approaches, a number of relevant genes have been identified and new information continually emerges to enrich the CBF cold-responsive pathway. However, the results of the transcriptome study demonstrate the highly complex nature of plant adaptation to low temperature. The fact that a large number of genes identified by these studies are currently annotated with "unknown function" and involve new genes and new pathways indicates that our knowledge of the transcriptional control of the low temperature response is limited, and the regulation of these transcriptional responses is far more complex than previously believed. Indeed, what we have understood about the cold-regulatory network is an edge of the iceberg. Information on the lowtemperature transcriptome, proteome and metabolome is expected to continue to increase in the near future. This information is necessary for our understanding of the complex network of molecular changes that are important for chilling and freezing tolerance.

\section{REFERENCES}

AGARWAL, Manu; HAO, Yujin; KAPOOR, Avnish; DONG, Chun-Hai; FUJII, Hiroaki; ZHENG, Xianwu and ZHU, Jian-Kang.A R2R3 type MYB transcription factor is involved in the cold regulation of CBF genes and in acquired freezing tolerance. Journal of Biological Chemistry, December 2006, vol. 281, no. 49, p. 3763637645.

ANCHORDOGUY, Thomas J.; RUDOLPH, Alan S.; CARPENTER, John F. and CROWE, John H. Modes of interaction of cryoprotectants with membrane 
phospholipids during freezing. Cryobiology, August 1987, vol. 24, no. 4, p. 324-331.

AROCA, Ricardo; IRIGOYEN, Juan José and SÁNCHEZDÍAZ, Manuel.Drought enhances maize chilling tolerance. II. Photosynthetic traits and protective mechanisms against oxidative stress. Physiologia Plantarum, April 2003, vol. 117, no. 4, p. 540-549.

ARTUS, Nancy N.; UEMURA, Matsuo; STEPONKUS, Peter L.; GILMOUR, Sarah J.; LIN, Chentao and THOMASHOW, Michael F. Constitutive expression of the cold-regulated Arabidopsis thaliana COR15a gene affects both choroplast and protoplast freezing tolerance. Proceedings of the National Academy of Sciences of the United States of America, November 1996, vol. 93, no. 23, p. 13404-13409.

BRAY, Elizabeth A. Genes commonly regulated by waterdeficit stress in Arabidopsis thaliana. Journal of Experimental Botany, November 2004, vol. 55, no. 407, p. 2331-2341.

CHINNUSAMY, Viswanathan; OHTA, Masaru; KANRAR, Siddhartha; LEE, Byeong-ha; HONG, Xuhui; AGARWAL, Manu and ZHU, Jian-Kang. ICE1: a regulator of cold-induced transcriptome and freezing tolerance in Arabidopsis. Genes and Development, April 2003, vol. 17, no. 8, p. 1043-1054.

CHINNUSAMY, Viswanathan; ZHU, Jianhua and ZHU, Jian-Kang. Gene regulation during cold acclimation in plants. Physiologia Plantarum, January 2006, vol. 126, no. 1, p. 52-61.

CHOI, Dong-Woog; RODRIGUEZ, Edmundo $M$. and CLOSE, Timothy J. Barley Cbf3 gene identification, expression pattern, and map location. Plant Physiology,August 2002, vol. 129, no. 4, p. 1781-1787.

CUSHMAN, John C. and BOHNERT, Hans J. Genomic approaches to plant stress tolerance. Current Opinion in Plant Biology, April 2000, vol. 3, no. 2, p. 117-124.

DAVLETOVA, Sholpan; SCHLAUCH, Karen; COUTU, Jesse and MITTLER, Ron. The zinc-finger protein Zat12 plays a central role in reactive oxygen and abiotic stress signaling in Arabidopsis. Plant Physiology, October 2005, vol. 139, no. 2, p. 847-856.

DONG, Chun-Hai; HU, Xiangyang; TANG, Weiping; ZHENG, Xianwu; KIM, Yong Sig; LEE, Byeong-ha and ZHU, Jian-Kang. A putative Arabidopsis nucleoporin, AtNUP160, is critical for RNA export and required for plant tolerance to cold stress. Molecular and Cell Biology, December 2006, vol. 26, no. 24, p. 9533-9543.

DUBOUZET, Joseph G.; SAKUMA, Yoh; ITO, Yysuke; KASUGA, Mie; DUBOUZET, Emilyn G.; MIURA, Setsuko; SEKI, Motoaki; SHINOZAKI, Kazuo and
YAMAGUCHI-SHINOZAKI, Kazuko. OsDREB genes in rice, Oryza sativa L., encode transcription activators that function in drought-, high-salt- and cold-responsive gene expression. The Plant Journal, February 2003, vol. 33, no. 4, p. 751-763.

EPAND, R.M.; SHAI, Y.; SEGREST, J.P. and ANANTHARAMAIAH, G.M. Mechanisms for the modulation of membrane bilayer properties by amphipathic helical peptides. Biopolymers, 1995, vol. 37, no. 5, p. 319338.

FOWLER, D.B. and GUSTA, L.V. Selection for winter hardiness in wheat. I. Identification of genotypic variability. Crop Science, November 1979, vol. 19, no. 6, p. 769-772.

FOWLER, Sarah and THOMASHOW, Michael F. Arabidopsis transcriptome profiling indicates that multiple regulatory pathways are activated during cold acclimation in addition to the CBF cold response pathway. The Plant Cell, August 2002, vol. 14, no. 8, p. 1675-1690.

FRANCIA, E.; RIZZA, F.; CATTIVELLI, L.; STANCA, A.M.; GALIBA, G.; TOTH, B.; HAYES, P.M.; SKINNER, J.S. and PECCHIONI, N. Two loci on chromosome $5 \mathrm{H}$ determine low-temperature tolerance in a 'Nure' (winter) $\mathrm{x}$ 'Tremois' (spring) barley map. Theoretical and Applied Genetics, February 2004, vol. 108, no. 4, p. 670-680.

GAO, Ming-Jun; ALLARD, Ghislaine; BYASS, Louise; FLANAGAN, Anne M. and SINGH, Jas. Regulation and characterization of four $C B F$ transcription factors from Brassica napus. Plant Molecular Biology, July 2002, vol. 49, no. 5, p. 459-471.

GILMOUR, Sarah J.; ZARKA, Daniel G.; STOCKINGER, Eric J.; SALAZAR, Maite P.; HOUGHTON, Jaimie M. and THOMASHOW, Michael F. Low temperature regulation of the Arabidopsis CBF family of AP2 transcriptional activators as an early step in cold-induced COR gene expression. The Plant Journal, November 1998, vol. 16, no. 4, p. 433-442.

GILMOUR, Sarah J.; SEBOLT, Audrey M.; SALAZAR, Maite P.; EVERARD, John D. and THOMASHOW, Michael F. Overexpression of the Arabidopsis CBF3 transcriptional activator mimics multiple biochemical changes associated with cold acclimation. Plant Physiology, December 2000, vol. 124, no. 4, p. 1854-1865.

GILMOUR, Sarah J.; FOWLER, Sarah G. and THOMASHOW, Michael F. Arabidopsis transcriptional activators CBF1, CBF2, and CBF3 have matching functional activities. Plant Molecular Biology, March 2004, vol. 54, no. 5, p. 767-781.

GOMÈS, Eric; JAKOBSEN, Mia K.; AXELSEN, Kristian B.; GEISLER, Marcus and PALMGREEN, Michael G. Chilling tolerance in Arabidopsis involves ALA1, a member of a new family of putative aminophospholipid 
translocases. Plant Cell, December 2000, vol. 12, no. 12, p. 2441-2453.

GONG, Zhizhong; LEE, Hojoung; XIONG, Liming; JAGENDORF, André; STEVENSON, Becky and ZHU, Jian-Kang. RNA helicase-like protein as an early regulator of transcription factors for plant chilling and freezing tolerance. Proceedings of the National Academy of Sciences of the United States of America, August 2002, vol. 99, no. 17, p. 11507-11512.

GONG, Zhizhong; DONG,Chun-Hai; LEE, Hojoung; ZHU, Jianhua; XIONG, Liming; GONG, Deming; STEVENSON, Becky and ZHU, Jian-Kang. A DEAD box RNA helicase is essential for mRNA export and important for development and stress responses in Arabidopsis. Plant Cell, January 2005, vol. 17, no. 1, p. 256-267.

GUY, Charles and LI, Qin Bao. The organization and evolution of the spinach stress 70 molecular chaperone gene family. Plant Cell, April 1998, vol. 10, no. 4, p. 539556.

GUY, Charles; HASKELL, Dale and LI, Qin Bao. Association of proteins with the stress 70 molecular chaperones at low temperature: evidence for the existence of cold labile proteins in spinach. Cryobiology, June 1998, vol. 36, no. 4, p. 301-314.

HAAKE, Volker; COOK, Daniel; RIECHMANN, José Luis; PINEDA, Omaira; THOMASHOW, Michael F. and ZHANG, James Z. Transcription factor CBF4 is a regulator of drought adaptation in Arabidopsis. Plant Physiology, October 2002, vol. 130, no. 2, p. 639-648.

HAJELA, Ravindra K.; HORVATH, David P.; GILMOUR, Sarah J. and THOMASHOW, Michael F. Molecular cloning and expression of cor (cold-regulated) genes in Arabidopsis thaliana. Plant Physiology, August 1990, vol. 93, no. 4, p. 1246-1252.

HARA, Masakazu; TERASHIMA, Shogo; FUKAYA, Tomoko and KUBOI, Toru. Enhancement of cold tolerance and inhibition of lipid peroxidation by citrus dehydrin in transgenic tobacco. Planta, June 2003, vol. 217, no. 2, p. 290-298.

HOLMBERG, Niklas and BULOW, Leif. Improving stress tolerance in plants by gene transfer. Trends in Plant Science, February 1998, vol. 3, no. 2, p. 61-66.

HOLMBERG, Niklas; FARRÉS, Judith; BAILEY, James E. and KALLIO, Pauli T. Targeted expression of a synthetic codon optimized gene, encoding the spruce budworm antifreeze protein, leads to accumulation of antifreeze activity in the apoplasts of transgenic tobacco. Gene, September 2001, vol. 275, no. 1, p. 115-124.

HORVÁTH, Ibolya; GLATZ, Attila; VARVASOVSZKI, Viktória; TOROK, Zsolt; PALI, Tibor; BALOGH, Gábor;
KOVACS, Eszter; NADASDI, Levente; BENKO, Sándor; JOÓ, Ferenc and VIGH, László. Membrane physical state controls the signaling mechanism of the heat shock response in Synechocystis PCC 6803: identification of hsp17 as a 'fluidity gene'. Proceedings of the National Academy of Sciences of the United States of America, March 1998, vol. 95, no. 7, p. 3513-3518.

HOUDE, Mario; DALLAIRE, Sylvain; N'DONG, Daniel and SARHAN, Fathey. Overexpression of the acidic dehydrin WCOR410 improves freezing tolerance in transgenic strawberry leaves. Plant Biotechnology Journal, September 2004, vol. 2, no. 5, p. 381-387.

HSIEH, Tsai-Hung; LEE, Jent-Turn; YANG, Pei-Tzu; CHIU, Li-Hui; CHARNG, Yee-yung; WANG, Yu-Chie and CHAN, Ming-Tsair. Heterology expression of the Arabidopsis C-repeat/dehydration response element binding factor 1 gene confers elevated tolerance to chilling and oxidative stresses in transgenic tomato. Plant Physiology, July 2002, vol. 129, no. 3, p. 1086-1094.

HU, Yu Xin; WANG, Yong Hong; LIU, Xin Fang and LI, Jia Yang. Arabidopsis RAV1 is down-regulated by brassinosteroid and may act as a negative regulator during plant development. Cell Research, February 2004, vol. 14, no. 1, p. 8-15.

HUGLY, Suzanne and SOMERVILLE, Chris. A role for membrane lipid polyunsaturation in chloroplast biogenesis at low temperature. Plant Physiology, May 1992, vol. 99, no. 1, p. 197-202.

ISHITANI, Manabu; XIONG, Liming; STEVENSON, Becky and ZHU, Jian-Kang. Genetic analysis of osmotic and cold stress signal transduction in Arabidopsis: interactions and convergence of abscisic acid dependent and abscisic acid-independent pathways. The Plant Cell, November 1997, vol. 9, no. 11, p. 1935-1949.

ISHITANI, Manabu; XIONG, Liming; LEE, Hojoung; STEVENSON, Becky and ZHU, Jian-Kang. HOS1, a genetic locus involved in cold-responsive gene expression in Arabidopsis. The Plant Cell, July 1998, vol. 10, no. 7, p. 1151-1161.

ITURRIAGA, Gabriel; SCHNEIDER, Katharina; SALAMINI, Francesco and BARTELS, Dorothea. Expression of desiccation-related proteins from the resurrection plant Craterostigma plantagineum in transgenic tobacco. Plant Molecular Biology, November 1992, vol. 20, no. 3, p. 555-558.

JAGLO, Kirsten R.; KLEFF, Susanne; AMUNDSEN, Keenan L.; ZHANG, Xin; HAAKE, Volker; ZHANG, James Z.; DEITS, Thomas and THOMASHOW, Michael F. Components of the Arabidopsis C-repeat/dehydrationresponsive element binding factor cold-response pathway are conserved in Brassica napus and other plant species. 
Plant Physiology, November 2001, vol. 127, no. 3, p. 910917.

JAGLO-OTTOSEN, Kirsten R.; GILMOUR, Sarah J.; ZARKA, Daniel G.; SCHABENBERGER, Oliver and THOMASHOW, Michael F. Arabidopsis CBF1 overexpression induces $C O R$ genes and enhances freezing tolerance. Science, April 1998, vol. 280, no. 5360, p. 104106.

JONES, Pamela G. and INOUYE, Masayori. The coldshock response-a hot topic. Molecular Microbiology, 1994, vol. 11, no. 5, p. 811-818.

KASUGA, Mie; LIU, Qiang; MIURA, Setsuko; YAMAGUCHI-SHINOZAKI, Kazuko and SHINOZAKI, Kazuo. Improving plant drought, salt, and freezing tolerance by gene transfer of a single stress-inducible transcription factor. Nature Biotechnology, March 1999, vol. 17, no. 3, p. 287-291.

KASUGA, Mie; Miura, SETSUKO; Shinozaki, Kazuo and YAMAGUCHI-SHINOZAKI, Kazuko A combination of the Arabidopsis DREB1A gene and stress-inducible $r d 29 A$ promoter improved drought and low-temperature stress tolerance in tobacco by gene transfer. Plant and Cell Physiology, 2004, vol. 45, no. 3, p. 346-350.

KAWASAKI, Shinji; BORCHERT, Chris; DEYHOLOS, Michael; WANG, Hong; BRAZILLE, Susan; KAWAI, Kiyoshi; GALBRAITH, David and BOHNERT, Hans J. Gene expression profiles during the initial phase of salt stress in rice. The Plant Cell, April 2001, vol. 13, no. 4, p. 889-905.

KAYE, Claudia; NEVEN, Lisa; HOFIG, Andrea; LI, QinBao; HASKELL, Dale and GUY, Charles. Characterization of a gene for spinach CAP160 and expression of two spinach cold-acclimation proteins in tobacco. Plant Physiology, April 1998, vol. 116, no. 4, p. 1367-1377.

KIM, Jin Sun; PARK, Su Jung; KWAK, Kyung Jin; KIM, Yeon Ok; KIM, Joo Yeol; SONG, Jinkyung; JANG, Boseung; JUNG, Che-Hun and KANG, Hunseung. Cold shock domain proteins and glycine-rich RNA-binding proteins from Arabidopsis thaliana can promote the cold adaptation process in Escherichia coli. Nucleic Acids Research, January 2007, vol. 35, no. 2, p. 506-516.

KIM, Jong Cheol; LEE, Sang Hyoung; CHEONG, Yong Hwa; YOO, Cheol-Min; LEE, Soo In; CHUN, Hyun Jin; YUN, Dae-Jin; HONG, Jong Chan; LEE, Sang Yeol; LIM, Chae Oh and CHO, Moo Je. A novel cold-inducible zinc finger protein from soybean, SCOF-1, enhances cold tolerance in transgenic plants. The Plant Journal, February 2001, vol. 25, no. 3, p. 247-259.

KIM, Yeon-Ok; KIM, Jin Sun and KANG, Hunseung. Cold-inducible zinc finger-containing glycine-rich RNAbinding protein contributes to the enhancement of freezing tolerance in Arabidopsis thaliana. The Plant Journal, June 2005, vol. 42, no. 6, p. 890-900.

KREPS, Joel A.; WU, Yajun; CHANG, Hur-Song; ZHU, Tong; WANG, Xun and HARPER, Jeff F. Transcriptome changes for Arabidopsis in response to salt, osmotic, and cold stress. Plant Physiology, December 2002, vol. 130, no. 4, p. 2129-2141.

KURKELA, Sirpa and FRANCK, Marianne. Cloning and characterization of a cold- and ABA-inducible Arabidopsis gene. Plant Molecular Biology, February 1990, vol. 15, no. 2, p. 137-144.

LEE, Byeong-ha; HENDERSON, David A. and ZHU, JianKang. The Arabidopsis cold-responsive transcriptome and its regulation by ICE1. The Plant Cell, November 2005, vol. 17, no. 11, p. 3155-3175.

LEE, Hojoung; XIONG, Liming; ISHITANI, Manabu; STEVENSON, Becky and ZHU, Jian-Kang. Cold-regulated gene expression and freezing tolerance in an Arabidopsis thaliana mutant. The Plant Journal, February 1999, vol. 17, no. 3, p. 301-308.

LEE, Hojoung; XIONG, Liming; GONG, Zhizhong; ISHITANI, Manabu; STEVENSON, Becky and ZHU, JianKang. The Arabidopsis HOS1 gene negatively regulates cold signal transduction and encodes a RING finger protein that displays cold-regulated nucleocytoplasmic partitioning. Genes and Development, April 2001, vol. 15, no. 7, p. 912924.

LEE, Hojoung; GUO, Yan; OHTA, Masaru; XIONG, Liming; STEVENSON, Becky and ZHU, Jian-Kang. LOS2, a genetic locus required for cold responsive transcription encodes a bi-functional enolase. EMBO Journal, June 2002, vol. 21, no. 11, p. 2692-2702.

LEVITT, J. Responses of plants to environmental stress. In: Chilling, Freezing, and High Temperature Stress. New York, Academic Press, 1980, vol. 1.

LIU, Qiang; KASUGA, Mie; SAKUMA, Yoh; ABE, Hiroshi; MIURA, Setsuko; YAMAGUCHI-SHINOZAKI, Kazuko and SHINOZAKI, Kazuo. Two transcription factors, DREB1 and DREB2, with an EREBP/AP2 DNA binding domain separate two cellular signal transduction pathways in drought and low-temperature-responsive gene expression, respectively, in Arabidopsis. The Plant Cell, August 1998, vol. 10, no. 8, p. 1391-1406.

LIVINGSTON, David P. and HENSON, Cynthia A. Apoplastic sugars, fructans, fructan exohydrolase, and invertase in winter oat: responses to second-phase cold hardening. Plant Physiology, January 1998, vol. 116, no. 1, p. 403-408.

LLORENTE, Francisco; OLIVEROS, Juan C.; MARTINEZ-ZAPATER, José M. and SALINAS, Julio. A 
freezing-sensitive mutant of Arabidopsis, frs1, is a new aba3 allele. Planta, October 2000, vol. 211, no. 5, p. 648655.

MARUYAMA, Kyonoshin; SAKUMA, Yoh; KASUGA, Mie; ITO, Yusuke; SEKI, Motoaki; GODA, Hideki; SHIMADA, Yukihisa; YOSHIDA, Shigeo; SHINOZAKI, Kazuo and YAMAGUCHI-SHINOZAKI, Kazuko. Identification of cold-inducible downstream genes of the Arabidopsis DREB1A/CBF3 transcriptional factor using two microarray systems. The Plant Journal, June 2004, vol. 38, no. 6, p. 982-993.

MCKERSIE, Bryan D.; BOWLEY, Stephen R. and JONES, Kim S. Winter survival of transgenic alfalfa overexpressing superoxide dismutase. Plant Physiology, March 1999, vol. 119, no. 3, p. 839-847.

MCKERSIE, Bryan D.; MURNAGHAN, Julia; JONES, Kim S. and BOWLEY, Stephen R. Iron-superoxide dismutase expression in transgenic alfalfa increases winter survival without a detectable increase in photosynthetic oxidative stress tolerance. Plant Physiology, April 2000, vol. 122, no. 4, p. 1427-1438.

MITTLER, Ron; KIM, Yong Sig; SONG, Luhua; COUTU, Jesse; COUTU, Alicia; CIFTCI-YILMAZ, Sultan; LEE, Hojoung; STEVENSON, Becky and ZHU, Jian-Kang. Gain- and loss-of-function mutations in Zat10 enhance the tolerance of plants to abiotic stress. FEBS Letters, December 2006, vol. 580, no. 28-29, p. 6537-6542.

MIURA, Kenji; JIN, Jing Bo; LEE, Jiyoung; YOO, Chan Yul; STIRM, Vicki; MIURA, Tomoko; ASHWORTH, Edward N.; BRESSAN, Ray A.; YUN, Dae-Jin and HASEGAWA, Paul M. SIZ1-mediated sumoylation of ICE1 controls CBF3/DREB1A expression and freezing tolerance in Arabidopsis. Plant Cell, April 2007, vol. 19, no. 4, p. 1403-1414.

MONROY, Antonio F.; CASTONGUAY, Yves; LABERGE, Serge; SARHAN, Fathey; VEZINA, Louis P. and DHINDSA, Rajinder S. A new cold-induced alfalfa gene is associated with enhanced hardening at subzero temperature. Plant Physiology, July 1993, vol. 102, no. 3, p. 873-879.

NAKAMINAMI, Kentaro; KARLSON, Dale T. and IMAI, Ryozo. Functional conservation of cold shock domains in bacteria and higher plants. Proceedings of the National Academy of Sciences of the United States of America, June 2006, vol. 103, no. 26, p. 10122-10127.

NANJO, Tokihiko; KOBAYASHI, Masatomo; YOSHIBA, Yoshu; KAKUBARI, Yoshitaka; YAMAGUCHISHINOZAKI, Kazuko and SHINOZAKI, Kazuo. Antisense suppression of proline degradation improves tolerance to freezing and salinity in Arabidopsis thaliana. FEBS Letters, November 1999, vol. 461, no. 3, p. 205-210.
NDONG, Christian; DANYLUK, Jean; WILSON, Kenneth E.; POCOCK, Tessa; HUNER, Norman P.A. and SARHAN, Fathey. Cold-regulated cereal chloroplast late embryogenesis abundant-like proteins. Molecular characterization and functional analysis. Plant Physiology, July 2002, vol. 129, no. 3, p. 1368-1381.

NORDIN, Kerstin; VAHALA, Tiina and PALVA, E. Tapio.Differential expression of two related, lowtemperature-induced genes in Arabidopsis thaliana (L.) Heynh. Plant Molecular Biology, February 1993, vol. 21, no. 4, p. 641-653.

NOVILLO, Fernando; ALONSO, José M.; ECKER, Joseph R. and SALINAS, Julio. CBF2/DREB1C is a negative regulator of $C B F 1 / D R E B 1 B$ and $C B F 3 / D R E B 1 A$ expression and plays a central role in stress tolerance in Arabidopsis. Proceedings of the National Academy of Sciences of the United States of America, March 2004, vol. 101, no. 11, p. 3985-3990.

OLIEN, C.R. and SMITH, M.N. Ice adhesions in relation to freeze stress. Plant Physiology, October 1977, vol. 60, no. 4, p. 499-503.

ORVAR, Björn Lárus; SANGWAN, Veena; OMANN, Franz and DHINDSA, Rajinder S. Early steps in cold sensing by plant cells: the role of actin cytoskeleton and membrane fluidity. The Plant Journal, September 2000, vol. 23, no. 6, p. 785-794.

OWENS, Christopher L.; THOMASHOW, Michael F.; HANCOCK, James F. and IEZZONI, Amy F. CBF1 orthologs in sour cherry and strawberry and the heterologous expression of CBF1 in strawberry. Journal of the American Society of Horticultural Science, July 2002, vol. 127, p. 489-494.

PELLEGRINESCHI, Alessandro; REYNOLDS, Matthew; PACHECO, Mario; BRITO, Rosa Maria; ALMERAYA, Rosaura; YAMAGUCHI-SHINOZAKI, Kazuko and HOISINGTON, David. Stress-induced expression in wheat of the Arabidopsis thaliana DREB1A gene delays water stress symptoms under greenhouse conditions. Genome, June 2004, vol. 47, no. 3, p. 493-500.

PUHAKAINEN, Tuula; HESS, Michael W.; MÄKELÄ, Pirjo; SVENSSON, Jan; HEINO, Pekka and PALVA, E. Tapio. Overexpression of multiple dehydrin genes enhances tolerance to freezing stress in Arabidopsis. Plant Molecular Biology, March 2004, vol. 54, no. 5, p. 743-753.

RABBANI, M. Ashiq; MARUYAMA, Kyonoshin; ABE, Hiroshi; KHAN, M. Ayub; KATSURA, Koji; ITO, Yusuke; YOSHIWARA, Kyoko; SEKI, Motoaki; SHINOZAKI, Kazuo and YAMAGUCHI-SHINOZAKI, Kazuko. Monitoring expression profiles of rice genes under cold, drought, and high-salinity stresses and abscisic acid application using cDNA microarray and RNA gel-blot 
analyses. Plant Physiology, December 2003, vol. 133, no. 4, p. 1755-1767.

RAPACZ, M. and MARKOWSKI, A. Winter hardiness, frost resistance and vernalization requirement of European winter oilseed rape (Brassica napus var. oleifera) cultivars within the last 20 years. Journal of Agronomy and Crop Science, 1999, vol. 183, no. 4, p. 243-253.

ROUTABOUL, Jean-Marc; FISCHER, Steven F. and BROWSE, John. Trienoic fatty acids are required to maintain chloroplast function at low temperatures. Plant Physiology, December 2000, vol. 124, no. 4, p. 1697-1705.

SARHAN, Fathey and DANYLUK, Jean. Engineering cold-tolerant crops-throwing the master switch. Trends in Plant Science, August 1998, vol. 3, no. 8, p. 289-290.

SEKI, Motoaki; NARUSAKA, Mari; ABE, Hiroshi; KASUGA, Mie; YAMAGUCHI-SHINOZAKI, Kazuko; CARNINCI, Piero; HAYASHIZAKI, Yoshihide and SHINOZAKI, Kazuo. Monitoring the expression pattern of 1300 Arabidopsis genes under drought and cold stresses by using a full-length cDNA microarray. Plant Cell, January 2001, vol. 13, no. 1, p. 61-72.

SEKI, Motoaki; NARUSAKA, Mari; ISHIDA, Junko; NANJO, Tokihiko; FUJITA, Miki; OONO, Youko; KAMIYA, Asako; NAKAJIMA, Maiko; ENJU, Akiko; SAKURAI, Tetsuya; SATOU, Masakazu; AKIYAMA, Kenji; TAJI, Teruaki; YAMAGUCHI-SHINOZAKI, Kazuko; CARNINCI, Piero; KAWAI, Jun; HAYASHIZAKI, Yoshihide and SHINOZAKI, Kazuo.Monitoring the expression profiles of 7000 Arabidopsis genes under drought, cold and high-salinity stresses using a full-length cDNA microarray. The Plant Journal, August 2002, vol. 31, no. 3, p. 279-292.

SEKI, Motoaki; KAMEI, Ayako; YAMAGUCHISHINOZAKI, Kazuko and SHINOZAKI, Kazuo. Molecular responses to drought, salinity and frost: common and different paths for plant protection. Current Opinion in Biotechnology, April 2003, vol. 14, no. 2, p. 194-199.

SEKI, Motoaki; SATOU, Masakazu; SAKURAI, Tetsuya; AKIYAMA, Kenji; IIDA, Kei; ISHIDA, Junko; NAKAJIMA, Maiko; ENJU, Akiko; NARUSAKA, Mari; FUJITA, Miki; OONO, Youko; KAMEI, Ayako; YAMAGUCHI-SHINOZAKI, Kazuko and SHINOZAKI, Kazuo. RIKEN Arabidopsis full length (RAFL) cDNA and its applications for expression profiling under abiotic stress conditions. Journal of Experimental Botany, January 2004, vol. 55, no. 395, p. 213-223.

SHEN, Y.G.; ZHANG, W.K.; He, S.J.; Zhang, J.S.; Liu, Q. and Chen, S.Y. An EREBP/AP2-type protein in Triticum aestivum was a DRE-binding transcription factor-induced by cold dehydration and ABA stress. Theoretical and Applied Genetics, March 2003, vol. 106, no. 5, p. 923-930.
SHINOZAKI, Kazuo and YAMAGUCHI-SHINOZAKI, Kazuko. Molecular response to drought and cold stress. Current Opinion in Biotechnology, April 1996, vol. 7, no. 2, p. 161-167.

SHINOZAKI, Kazuo and YAMAGUCHI-SHINOZAKI, Kazuko. Molecular responses to dehydration and low temperature: differences and cross-talk between two stress signaling pathways. Current Opinion in Plant Biology, June 2000, vol. 3, no. 3, p. 217-223.

SHINOZAKI, Kazuo; YAMAGUCHI-SHINOZAKI, Kazuko and SEKI, Motoaki. Regulatory network of gene expression in the drought and cold stress responses. Current Opinion in Plant Biology, October2003, vol. 6, no. 5, p. 410-417.

STEPONKUS, Peter L. Role of the plasma membrane in freezing injury and cold acclimation. Annual Reviews of Plant Physiology, 1984, vol. 35, p. 543-584.

STEPONKUS, P.L.; UEMURA, M. and WEBB, M.S. A contrast of the cryostability of the plasma membrane of winter rye and spring oat-two species that widely differ in their freezing tolerance and plasma membrane lipid composition. In: STEPONKUS, P.L. ed. Advances in LowTemperature Biology. London, JAI Press, 1993, vol. 2, p. 211-312.

STOCKINGER, Eric J.; GILMOUR, Sarah J. and THOMASHOW, Michael F. Arabidopsis thaliana CBF1 encodes an AP2 domain-containing transcriptional activator that binds to the C-repeat/DRE, a cis-acting DNA regulatory element that stimulates transcription in response to low temperature and water deficit. Proceedings of the National Academy of Sciences of the United States of America, February 1997, vol. 94, no. 3, p. 1035-1040.

STRAUSS, G. and HAUSER, H. Stabilization of lipid bilayer vesicles by sucrose during freezing. Proceedings of the National Academy of Sciences of the United States of America, April 1986, vol. 83, no. 8, p. 2422-2426.

TEIGE, Markus; SCHEIKL, Elisabeth; EULGEM, Thomas; DOCZI, Róbert; ICHIMURA, Kazuya; SHINOZAKI, Kazuo; DANGL, Jeffery L. and HIRT, Heribert. The MKK2 pathway mediates cold and salt stress signaling in Arabidopsis. Molecular Cell, July 2004, vol. 15, no. 1, p. 141-152.

TESTER, Mark and BACIC, Antony. Abiotic stress tolerance in grasses. From model plants to crop plants. Plant Physiology,March 2005, vol. 137, no. 3, p. 791-793.

THOMASHOW, Michael F. Molecular genetics of cold acclimation in higher plants. Advances in Genetics, 1990, vol. 28, p. 99-131. 
THOMASHOW, Michael F. Role of cold-responsive genes in plant freezing tolerance. Plant Physiology, September 1998, vol. 118, no. 1, p. 1-8.

THOMASHOW, Michael F. Plant cold acclimation: freezing tolerance genes and regulatory mechanisms. Annual Review of Plant Physiology and Plant Molecular Biology, 1999, vol. 50, p. 571-599.

THOMASHOW, Michael F. So what's new in the field of plant cold acclimation? Lots! Plant Physiology, January 2001, vol. 125, no. 1, p. 89-93.

ULRICH, Helle D. Mutual interactions between the SUMO and ubiquitin systems: A plea of no contest. Trends in Cell Biology, October 2005, vol. 15, no. 10, p. 525-532.

VÁGÚJFALVI, A.; GALIBA, G.; CATTIVELLI, L. and DUBCOVSKY, J. The cold regulated transcriptional activator $C b f 3$ is linked to the frost-tolerance locus Fr-A2 on wheat chromosome 5A. Molecular Genetics and Genomics, April 2003, vol. 269, no. 1, p. 60-67.

VINOCUR, Basia and ALTMAN, Arie. Recent advances in engineering plant tolerance to abiotic stress: achievements and limitations. Current Opinion in Biotechnology, April 2005, vol. 16, no. 2, p. 123-132.

VLACHONASIOS, Konstantinos E.; THOMASHOW, Michael F. and TRIEZENBERG, Steven J. Disruption mutations of $A D A 2 b$ and GCN5 transcriptional adaptor genes dramatically affect Arabidopsis growth, development, and gene expression. The Plant Cell, March 2003, vol. 15, no. 3, p. 626-638.

VOGEL, Jonathan T.; ZARKA, Daniel G.; VAN BUSKIRK, Heather A.; FOWLER, Sarah G. and THOMASHOW, Michael F. Roles of the CBF2 and ZAT12 transcription factors in configuring the low temperature transcriptome of Arabidopsis. The Plant Journal, November 2005, vol. 41, no. 2, p. 195-211.

WU, J.,LIGHTNER, J., WARWICK, N. and BROWSE. J. Low-temperature damage and subsequent recovery of fab1 mutant Arabidopsis exposed to $28^{\circ} \mathrm{C}$. Plant Physiology, February 1997, vol. 113, no. 2, p. 347-356.

XIN, Zhanguo and BROWSE, John. Eskimo1 mutants of Arabidopsis are constitutively freezing-tolerant. Proceedings of the National Academy of Sciences of the United States of America, June 1998, vol. 95, no. 13, p. 7799-7804.

XIN, Zhanguo and BROWSE, John. Cold comfort farm: the acclimation of plants to freezing temperatures. Plant Cell and Environment, September 2000, vol. 23, no. 9, p. 893-902.

XIN, Zhanguo; MANDAOKAR, Ajin; CHEN, Junping; LAST, Robert L. and BROWSE, John. Arabidopsis ESK1 encodes a novel regulator of freezing tolerance. The Plant Journal, March 2007, vol. 49, no. 5, p. 786-799.

XUE, Gang-Ping. The DNA-binding activity of an AP2 transcriptional activator HvCBF2 involved in regulation of low-temperature responsive genes in barley is modulated by temperature. The Plant Journal, January 2003, vol. 33, no. 2, p. 373-383.

YAMAGUCHI-SHINOZAKI, Kazuko; KOIZUMI, Masahiro; URAO, Satomi and SHINOZAKI, Kazuo. Molecular cloning and characterization of 9 cDNAs for genes that are responsive to desiccation in Arabidopsis thaliana: sequence analysis of one cDNA clone that encodes a putative transmembrane channel protein. Plant Cell Physiology, April 1992, vol. 33, no. 3, p. 217-224.

YU, Esther and OWTTRIM, George W. Characterization of the cold stress-induced cyanobacterial DEAD-box protein CrhC as an RNA helicase. Nucleic Acids Research, October 2000, vol. 28, no. 20, p. 3926-3934.

ZHANG, James Z.; CREELMAN, Robert A. and ZHU, Jian-Kang. From laboratory to field. Using information from Arabidopsis to engineer salt, cold, and drought tolerance in crops. Plant Physiology, June 2004, vol. 135, no. 2, p. 615-621.

ZHU, Jianhua; SHI, Huazhong; LEE, Byeong-Ha; DAMSZ, Barbara; CHENG, Shie; STIRM, Vicki; ZHU, Jian-Kang; HASEGAWA, Paul M. and BRESSAN, Ray A. An Arabidopsis homeodomain transcription factor gene, HOS9, mediates cold tolerance through a CBF-independent pathway. Proceedings of the National Academy of Sciences of the United States of America, June 2004, vol. 101, no. 26, p. 9873-9878.

ZHU, Jianhua; VERSLUES, Paul E.; ZHENG, Xianwu; LEE, Byeong-Ha; ZHAN, Xiangqiang; MANABE, Yuzuki; SOKOLCHIK, Irina; ZHU, Yanmei; DONG, Chun-Hai; ZHU, Jian-Kang; HASEGAWA, Paul H. and BRESSAN, Ray A. HOS10 encodes an R2R3-type MYB transcription factor essential for cold acclimation in plants. Proceedings of the National Academy of Sciences of the United States of America, July 2005, vol. 102, no. 28, p. 9966-9971. 